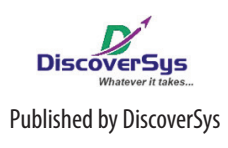

Published by DiscoverSys

\section{Differences in post-placental intra uterine device acceptance with and without couples counseling in private practice midwifery clinics, West Denpasar}

\author{
Putu Ayu Ratna Darmayanti,,$^{*}$ Dewa Nyoman Wirawan, ${ }^{2}$ \\ Komang Ayu Kartika Sari, ${ }^{2}$ Mangku Karmaya, ${ }^{3} \mathrm{Ni}$ Luh Putu Suariyani ${ }^{2}$
}

\title{
ABSTRACT
}

Background and purpose: The post-placental intra uterine device (IUD) program is one intervention to increase IUD uptake however the acceptance remains low. Contraceptive counseling during pregnancy is expected to increase IUD uptake. The primary objective of this study is to determine the efficacy of counseling by involving the husband in order to improve post-placental IUD uptake. The secondary objective is to compare knowledge and perceptions of IUD before and after intervention.

Methods: A randomized controlled trial was conducted with 58 pregnant women at 37-40 weeks' gestation in three private midwifery clinics in Denpasar, Bali. Subjects were divided into two groups: 29 intervention groups that were given couples counseling and 29 control groups that were given counseling without involving husbands. Base line interview was conducted during enrollment and follow up interview was carried out immediately after delivery.
Results: Acceptance of post-placental IUD was found in 21 women (72.41\%) in the intervention group and 10 women (34.48\%) in the control group ( $\mathrm{RR}=2.2 ; 95 \% \mathrm{Cl}: 1.23-3.84$ ). The mean difference in pretest and post-test scores of knowledge, perceptions of susceptibility and benefits were found to be higher in the intervention group but not statistically significant. The result of multivariate analysis indicated that the variables influencing post-placental IUD acceptance were the child's gender ( $A O R=45.9,95 \% \mathrm{Cl}: 4.53-465.25)$, couples counseling with husband (AOR=17.4, 95\% Cl: 2.55-119.56) and maternal education ( $A O R=7.1 ; 95 \% \mathrm{Cl}: 1.17-43.40)$.

Conclusions: Couples counseling was found to increase postplacental IUD uptake. In addition, post-placental IUD acceptance is also influenced by the child's gender and maternal education levels. To increase uptake of post-placental IUDs there is a need for upscalling of couples counseling at the time of antenatal care.

Keywords: Acceptance of post-placental IUD, couples counseling, Bali

Cite This Article: Darmayanti, P.A.R., Wirawan, D.N., Sari, K.A.K., Karmaya, M., Suariyani, N.L.P. 2018. Differences in post-placental intra uterine device acceptance with and without couples counseling in private practice midwifery clinics, West Denpasar. Public Health and Preventive Medicine Archive 6(1):4-9. D01:10.15562/phpma.v6i1.2

1Public Health Postgraduate Program Faculty of Medicine Udayana University, ${ }^{2}$ Department of Public Health and Preventive Medicine Faculty of Medicine Udayana University, ${ }^{3}$ Department of Anatomy Faculty of Medicine, Udayana University.

${ }^{*}$ Correspondence to: Putu Ayu Ratna Darmayanti, Public Health Postgraduate Program Faculty of Medicine Udayana University, darmayantiratna@gmail.com

\section{INTRODUCTION}

The main objective of the family planning program in Indonesia is to increase the use of long acting contraceptive methods such as tubectomy, vasectomy, implants and intra uterine devices (IUD). ${ }^{1}$ The proportion of tubectomy, vasectomy and implant acceptance in Indonesia has tended to increase from 1991 to 2012, although not significantly. ${ }^{2}$ However, IUD uptake tends to decline year by year, ie $13.3 \%$ in $1991,10.3 \%$ in $1994,8.1 \%$ in $1997,6.2 \%$ in $2002-2003,4.9 \%$ in 2007 and $3.9 \%$ in 2012. ${ }^{2}$ The proportion of IUD use in Bali is the highest nationally but also declined year by year, ie $23.8 \%$ in $2007,{ }^{3} 19.0 \%$ in $2012^{2}$ and $17.9 \%$ in $2013 .{ }^{4}$

One of the efforts undertaken to improve IUD uptake is through the promotion of the post-placental IUD program wherein the IUD is initiated immediately after birth to prevent missed opportunity, increase contraceptive prevalence rate (CPR), decrease unmet need, and accelerate the decline of maternal mortality rate. ${ }^{1}$ Previous study from the Wangaya General Hospital, Denpasar showed that post-placental IUD uptake was $35 \%$ of all mothers given counseling during pregnancy without involving husbands. ${ }^{5}$ The results of the study at Ulee Kareng (Banda Aceh) indicated that counseling involving husbands on a regular basis can help shape positive attitudes towards use of contraception. ${ }^{6}$ Case-control study conducted in Turkey showed that the support of husbands in the implementation of antenatal counseling may increase the use of post-placental IUD. ${ }^{7}$ Cross-sectional study conducted in antenatal clinics among pregnant women attending a tertiary health center in Puducherry, India found that having shared information with their husband can increase the wife's willingness to use post-placental IUD. ${ }^{8}$ 
The primary objective of this study is to determine the efficacy of counseling by involving the husband to improve post-placental IUD acceptance. The secondary objective is to compare knowledge and perceptions about IUD before and after intervention.

\section{METHODS}

A randomized controlled trial was conducted with 58 pregnant women at 37-40 weeks gestation in West Denpasar, Bali. The study was conducted from May to July 2017 in three private midwifery clinics with the inclusion criteria: serving delivery, providing post-placental IUD and having the most antenatal care (ANC) visits. The three private midwifery clinics in this study were certified in counseling and in post-placental IUD services. The inclusion criteria were all pregnant women with 37-40 weeks gestation who underwent ANC examinations in the three private midwifery clinics and who were willing to participate in the study. Exclusion criteria were: pregnant women with 37-40 weeks gestation who had rupture of membranes, high blood pressure, preeclampsia, anemia and infant abnormalities. Subjects were randomized into two groups of 29 women in the intervention group who were given counseling involving husbands, and 29 women in the control group who were given counseling without involving husbands. Block randomization was used based on the arrival of the subject to the private midwifery clinic. If the husband was not present at the time of counseling, the midwife contacted the husband and arranged a counseling schedule to ensure husband's attendance. However, if the husband could not be present then the subject was excluded from the study. If at the time of counselling the husband was forced to participate in counseling session, then the subject was also excluded from the study. Counseling was carried out one time in a private counseling room that had been prepared at the study site. Counseling was provided by the midwife for approximately 30 minutes using a flipchart as the education media. Counseling materials included basic IUD information, such as the advantages, disadvantages, procedure and insertion time, benefits, side effects, and follow up schedule after insertion.

The minimum number of samples required in this study was 58 subjects, calculated with a $90 \%$ probability of being able to detect a relative increase in post-placental IUD acceptance by $52 \%$, with a significance level of 0.05 . Baseline interviews were conducted by midwives during enrollment after the subject signed an informed consent form and were conducted in a designated space separate from the ANC examination room. Before conducting the interview, the midwife was trained by the researchers. Data collected in the interview were demographic characteristics of mothers and husbands, plans for contraceptive use after delivery, knowledge and perceptions about post-placental IUD, and husband support in contraceptive selection and use. The questionnaire to measure the perceptions of the women was referring to the Health Belief Model (HBM). Each interview took approximately 15 minutes. Follow up interviews were conducted immediately after delivery by the midwife in the study site.

Data were analysed using STATA SE 12.1. Relative risk (RR) was calculated to measure the efficacy of couples counseling. Differences in knowledge and perceptions were examined using independent t-test. Multivariate analysis with logistic regression was performed to determine factors related to post-placental IUD uptake. This study obtained Ethics Clearance on May 5th, 2017 from the Ethics Committee at the Faculty of Medicine Udayana University/ Sanglah General Hospital.

\section{RESULTS}

During May to July 2017 as many as 151 pregnant women with 37-40 weeks gestation presented at three private midwifery clinics (Figure 1). Of these, 64 subjects were eligible, but as many as 6 subjects were excluded from the study as they did not meet the inclusion criteria. The number of eligible subjects was 58 pregnant women, who randomly allocated to the intervention group (29 subjects) and the control group (29 subjects).

Characteristics of the subjects in the intervention and control groups are presented in Table 1. It was shown that the characteristics of the subjects were comparable according to age $(\mathrm{p}=0.570)$, education $(\mathrm{p}=0.991)$, parity $(\mathrm{p}=0.614)$, gender of the child $(\mathrm{p}=0.915)$, religion $(\mathrm{p}=0.945)$ and parental origin ( $\mathrm{p}=0.426$ ).

Post-placental IUD uptake was significantly higher in the intervention group with the number of 21 subjects (72.41\%) compared to the control group with 10 subjects $(34.48 \%)$ ( $R R=2.2 ; 95 \%$ CI: 1.23-3.84). IUD acceptance was found significantlyassociated with the gender of the child $(\mathrm{p}<0.01)$ and parental origin ( $\mathrm{p}=0.001)$, as shown in Table 2. The variables with $\mathrm{p}$ value $<0.25$ were included in the multivariate analysis model using logistic regression. Table 3 indicates that post-placental IUD acceptance was also associated with child gender $(\mathrm{AOR}=45.9 ; \quad 95 \% \mathrm{CI}: 4.53-465.25)$ and maternal education (AOR=7.1; 95\%CI: 1.17-43.40).

Secondary objective of this study was to explore the change in knowledge and perception of the subject before and after the intervention. The mean differences in pretest and post-test 


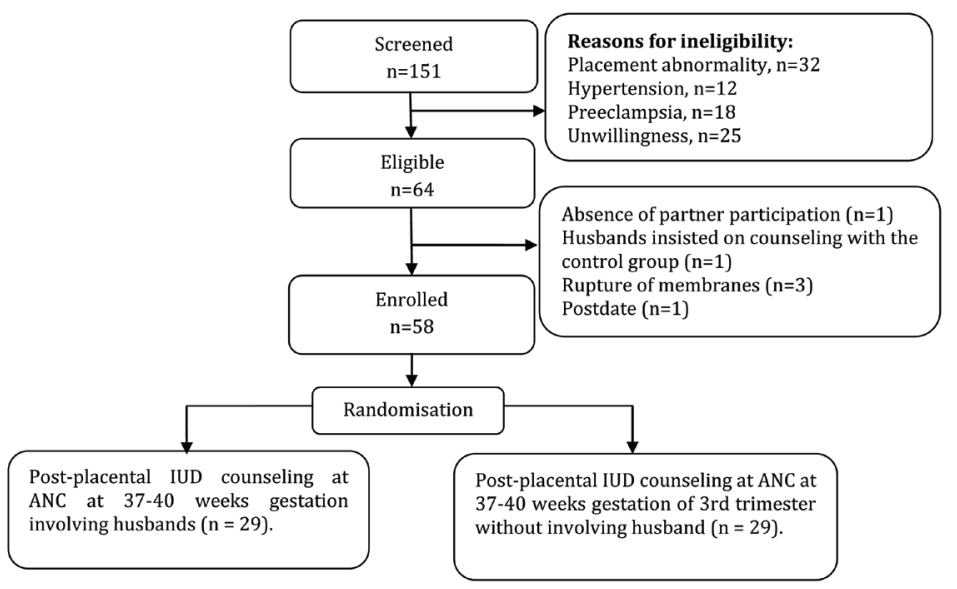

Figure 1 Subject selection and randomisation scores of knowledge, perceived susceptibility and perceived benefit were found to be higher in the intervention group but not statistically significant as shown in Table 4.

\section{DISCUSSION}

Studies on post-placental IUD acceptance in Indonesia have been widely conducted. ${ }^{5,6}$ However, in our knowledge, study on counseling interventions involving husbands at the time of antenatal care has never been published.

In this study, counseling involving husbands was found to significantly increase post-placental IUD acceptance of $72.41 \%$ compared to $34.48 \%$. A post-placental IUD study that did not involve husbands and conducted at Wangaya Denpasar

Table 1 Characteristics of intervention and control groups

\begin{tabular}{|c|c|c|c|c|c|}
\hline \multirow[t]{2}{*}{ Characteristic } & \multicolumn{2}{|c|}{ Intervention group } & \multicolumn{2}{|c|}{ Control group } & \multirow[t]{2}{*}{ p value } \\
\hline & $\mathbf{n}$ & $\%$ & $\mathbf{n}$ & $\%$ & \\
\hline \multicolumn{6}{|l|}{ Age (years) } \\
\hline $19-24$ & 10 & 34.48 & 12 & 41.38 & \multirow{4}{*}{0.570} \\
\hline $25-29$ & 10 & 34.48 & 12 & 41.38 & \\
\hline $30-34$ & 7 & 24.14 & 3 & 10.34 & \\
\hline $35-39$ & 2 & 6.90 & 2 & 6.90 & \\
\hline \multicolumn{6}{|l|}{ Education } \\
\hline Elementary & 7 & 24.14 & 6 & 20.69 & \multirow{5}{*}{0.991} \\
\hline Junior high school & 5 & 17.24 & 5 & 17.24 & \\
\hline Senior high school & 11 & 37.93 & 11 & 37.93 & \\
\hline Diploma & 2 & 6.90 & 3 & 10.34 & \\
\hline Tertiary & 4 & 13.79 & 4 & 13.79 & \\
\hline \multicolumn{6}{|l|}{ Parity } \\
\hline 1 & 8 & 27.59 & 12 & 41.38 & \multirow{4}{*}{0.614} \\
\hline 2 & 18 & 62.07 & 13 & 44.83 & \\
\hline 3 & 2 & 6.90 & 3 & 10.34 & \\
\hline 4 & 1 & 3.45 & 1 & 3.45 & \\
\hline \multicolumn{6}{|l|}{ Gender of child } \\
\hline Male & 21 & 72.41 & 19 & 65.52 & \multirow[t]{2}{*}{0.915} \\
\hline Female & 8 & 27.59 & 10 & 34.48 & \\
\hline \multicolumn{6}{|l|}{ Religion } \\
\hline Hindu & 15 & 51.72 & 15 & 51.72 & \multirow{4}{*}{0.945} \\
\hline Islam & 12 & 41.38 & 11 & 37.93 & \\
\hline Catholic & 1 & 3.45 & 1 & 3.45 & \\
\hline Protestant & 1 & 3.45 & 2 & 6.90 & \\
\hline \multicolumn{6}{|l|}{ Parental Origin } \\
\hline Bali & 18 & 62.07 & 15 & 51.72 & \multirow[t]{3}{*}{0.426} \\
\hline Outside Bali & 11 & 37.93 & 14 & 48.28 & \\
\hline Total & 29 & 100.00 & 29 & 100.00 & \\
\hline
\end{tabular}




\begin{tabular}{|c|c|c|c|}
\hline \multirow[b]{3}{*}{ Variable } & \multicolumn{2}{|c|}{ Post-placental IUD uptake } & \multirow[b]{3}{*}{ p value } \\
\hline & Use & Non-use & \\
\hline & n (\%) & n (\%) & \\
\hline \multicolumn{4}{|l|}{ Counseling } \\
\hline Intervention group & $21(72.41)$ & $8(27.59)$ & 0.004 \\
\hline Control group & $10(34.48)$ & $19(65.52)$ & \\
\hline \multicolumn{4}{|l|}{ Age } \\
\hline$\leq 27$ years & $16(53.33)$ & $14(46.67)$ & 0.986 \\
\hline 27 years and above & $15(53.57)$ & $13(46.43)$ & \\
\hline \multicolumn{4}{|l|}{ Mother's education } \\
\hline Junior high school and below & $10(43.48)$ & $13(56.52)$ & 0.217 \\
\hline Senior high school and above & $21(60.00)$ & $14(40.00)$ & \\
\hline \multicolumn{4}{|l|}{ Parity } \\
\hline$\leq 2$ children & $27(50.94)$ & $26(49.06)$ & 0.213 \\
\hline$>2$ children & $4(80.00)$ & $1(20.00)$ & \\
\hline \multicolumn{4}{|l|}{ Gender of child } \\
\hline Male & $28(70.00)$ & $12(30.00)$ & 0.000 \\
\hline Female & $3(16.67)$ & $15(83.33)$ & \\
\hline \multicolumn{4}{|l|}{ Religion } \\
\hline Non Hindu & $12(42.86)$ & $16(57.14)$ & 0.118 \\
\hline Hindu & $19(63.33)$ & $11(36.67)$ & \\
\hline \multicolumn{4}{|l|}{ Parental origin } \\
\hline Outside of Bali & $7(28.00)$ & $18(72.00)$ & 0.001 \\
\hline Bali & $24(72.73)$ & $9(27.27)$ & \\
\hline Total & $31(54.42)$ & $27(45.58)$ & \\
\hline
\end{tabular}

\begin{tabular}{|c|c|c|c|}
\hline Variable & Adjusted OR & $95 \% \mathrm{Cl}$ & p value \\
\hline \multicolumn{4}{|l|}{ Gender of child } \\
\hline Female & 1 (Ref) & & \\
\hline Male & 45.9 & $4.534-465.251$ & 0.001 \\
\hline \multicolumn{4}{|l|}{ Counseling } \\
\hline Without husband & 1 (Ref) & & \\
\hline With husband & 17.4 & $2.550-119.568$ & 0.004 \\
\hline \multicolumn{4}{|l|}{ Education of mother } \\
\hline Junior high school and below & 1 (Ref) & & \\
\hline Senior high school and above & 7.1 & $1.170-43.406$ & 0.033 \\
\hline
\end{tabular}

Hospital showed that IUD acceptance was 35\%. ${ }^{5}$ This finding was similar to this study where in uptake within the group of pregnant women without involving the husband was $34.48 \%$.

Several studies in other countries also indicated that the proportion of post-placental IUD acceptance without involving husbands was found to be similar as in the control group of our study and the study at Wangaya Hospital. A study conducted in India found $36 \%{ }^{9}$ and in Nigeria was $41 \%{ }^{10}$

The result of multivariate analysis showed that gender of the children and education levels also significantly associated with IUD acceptance. Mothers who already had sons and those with higher education tended to be more receptive to 
Table 4 Differences in knowledge and perceptions before and after counseling

\begin{tabular}{lcc}
\hline Variables & Intervention group & Control group \\
\hline Knowledge score & & \\
Pre-test $(95 \% \mathrm{CI})$ & $1.37(1.10-1.65)$ & $1.37(1.10-1.65)$ \\
Post-test $(95 \% \mathrm{CI})$ & $2.03(1.66-2.08)$ & $1.65(1.36-1.94)$ \\
Pretest-postest difference mean score & $0.66(0.41-0.91)$ & $0.28(0.03-0.53)$ \\
Perceived susceptibility score & & \\
Pre-test $(95 \% \mathrm{CI})$ & $5.0(4.25-5.74)$ & $4.37(3.80-4.95)$ \\
Post-test $(95 \% \mathrm{CI})$ & $5.65(4.94-6.36)$ & $5.0(4.25-5.74)$ \\
Pretest-postest difference mean score $(95 \% \mathrm{CI})$ & $0.65(0.35-1.66)$ & $0.63(0.29-1.53)$ \\
Perceived benefits score & & \\
Pre-test $(95 \% \mathrm{CI})$ & $3.34(2.81-3.87)$ & $7.10(6.46-7.74)$ \\
Post-test $(95 \% \mathrm{CI})$ & $4.17(3.65-4.69)$ & $1.07(0.06-2.07)$ \\
Pretest-postest difference mean score $(95 \% \mathrm{CI})$ & $0.83(0.10-1.55)$ &
\end{tabular}

post-placental IUD. This is undoubtedly connected to Balinese culture that is predominately patrilineal. This finding is also similar to the study at Wangaya Hospital which discovered that post-placental IUD uptake was higher in mothers who already had sons. ${ }^{5}$

With regards to the role of the husband, several other studies have also shown that acceptance of post-placental contraceptive is influenced by opinions of the partner. A cross-sectional study conducted in antenatal clinics in Puducherry, India showed that having shared information with their husband significantly increased the willingness of wives to use post-placental IUD $(\mathrm{p}<0.001){ }^{8}$ Case-control study conducted in Turkey found that the support of husband in the implementation of antenatal counseling increased the use of post-placental IUD. ${ }^{7}$ In this study, knowledge scores and perceived susceptibility scores were found to increase at post-test compared to pretest, but not statistically significant. Similarly, when comparisons were made between the intervention group and the comparison group, it was found that knowledge scores and perceived susceptibility scores were higher in the intervention group but not statistically significant. This is possibly due to the small number of samples. The perceived benefit scores at post-test were found to be higher than at the time of pretest, but also not statistically significant.

Changes in knowledge in several other intervention studies showed various results. Study in Vietnam indicated an increase in knowledge wherein IUD contraceptive counseling involving husbands impacted positively on the wife's readiness to use IUD. ${ }^{11}$ Other studies conducted in Nusa Tenggara Barat indicated a significant improvement in knowledge levels of pregnant women after being given post-placental IUD counseling than among those who had only received counseling beforehand. ${ }^{12}$ Study in Ungaran (Semarang) found that counseling increased the level of knowledge and interest of pregnant women on post-placental IUD. ${ }^{13}$ While a study in Turkey found no significant change in knowledge in the intervention group and in the control group that had been given postpartum counseling. ${ }^{14}$ The study at Wangaya Hospital indicated similar results with our study wherein perception of susceptibility and benefit were increased after counseling. ${ }^{5}$ In addition, post-placental IUD uptake was shown to be associated with low side effect perceptions and high benefit perceptions of post-placental IUD. ${ }^{5}$

The limitations of this study were the small sample size and number of sites. Study was only conducted at three private midwifery clinics in an urban area in Denpasar, Bali with a specific socio-cultural population therefore results can not be extrapolated into a wider target population.

\section{CONCLUSION}

Antenatal couples counseling was shown to significantly increase post-placental IUD uptake. Knowledge and perceptions of susceptibility were found to be higher in the intervention group but not statistically significant. To increase the use of post-placental IUD there is a need for up scaling of couples counseling involving the husband at the time of antenatal care.

\section{ACKNOWLEDGEMENT}

We would like to thank the private midwives and the subjects who participated in the study. 


\section{REFERENCES}

1. The National Demography and Family Planning Agency. Laporan Hasil Pelayanan Kontrasepsi, Bulan Juli 2015 (Report on Contraception Program Output, July 2015). Jakarta: The National Demography and Family Planning Agency; 2015.

2. Statistics Indonesia. Indonesia Demographic and Health Survey 2012. Jakarta, Indonesia: Statistics Indonesia; 2013

3. Statistics Indonesia. Indonesia Demographic and Health Survey 2007. Jakarta, Indonesia: Statistics Indonesia; 2008

4. Division of Health Research and Development Ministry of Health of Indonesia. Riset Kesehatan Dasar 2013 (The 2013 Basic Health Research). Jakarta: Ministry of Health of Indonesia; 2013.

5. Widiastuti, R. Penerimaan pelayanan alat kontrasepsi dalam rahim pasca plasenta di Kota Denpasar (Acceptance of post-placental intra uterine device in Denpasar City). Public Health and Preventive Medicine Archive; 2016; 4(1):104-110.

6. Darmawati. Pengaruh efektifitas konseling terhadap dukungan suami dalam pengambilan keputusan $\mathrm{KB}$ dan pemilihan kontrasepsi (Effectiveness of counseling on husband support in family planning and contraception decision making). Idea Nursing Journal; 2008; 3(1): 2087-2879.

7. Vural F, Vural B, Cakiroglu Y. The effect of combined antenatal and postnatal counseling on postpartum modern contraceptive use: prospective case-control study in Kocaeli, Turkey. Journal of Clinical and Diagnostic Research; 2016: 10(4):04-07.

8. Valliappan A, Dorairajan G, Chinnakali P. Postpartum intrauterine contraceptive device: Knowledge and factors affecting acceptance among pregnant/parturient women attending a large tertiary health center in Puducherry, India. International Journal of Advanced Medical and Health Research; 2017;4:69-74.

9. Kanhere AV, Pateriya P, Manisha J. Acceptability and feasibility of immediate postpartum IUCD insertion in a tertiary care centre in Central India. International Journal of Reproduction, Contraception, Obstetrics and Gynecology; 2015;4(1):179-184.
10. Eluwa GIe, Atamewalen R, Odogwu K, Ahonsi B. Success providing postpartum intrauterine devices in private-sector health care facilities in Nigeria: Factors associated with uptake. Global Health Science and Practice Journal; 2016; 4(2): 276-283.

11. Ha BTT, Jayasuriya R, Owen N. Increasing male involvement in family planning decision making: trial of a social-cognitive intervention Rural Vietnam. Oxford Journal Health Education Research; 2005; 20(5):548-556.

12. Dewi C, Ekayani K, Sopiatun R. Pengaruh pemberian konseling keluarga berencana $(\mathrm{KB})$ terhadap alat kontrasepsi IUD post plasenta di RSUP NTB tahun 2013 (The effect of family planning counseling on the use of post-placental IUD at West Nusa Tenggara Central Hospital, 2013). Jurnal Media Bina Ilmiah; 2013; 7(5):7-12.

13. Sari AM, Soeharto BP, Wulandari DR. Pengaruh konseling bidan terhadap tingkat pengetahuan dan minat menjadi akseptor IUD post plasenta di Kecamatan Ungaran Barat tahun 2016 (The effect of counseling by midwife on knowledge and intention to use post-placental IUD in West Ungaran District, 2016). Jurnal Kedokteran Diponegoro. 2017; 6(2): 328-336.

14. Akman M, Tuzun S, Uzuner A, Basgul A, Kavak Z. The influence of prenatal counseling on postpartum contraceptive choice. The Journal of International Medical Research. 2010; 38(4):1243 - 1249.

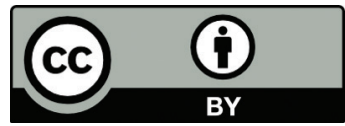

This work is licensed under a Creative Commons Attribution 